\title{
Effect of Grazing Stubble Height and Season on Establish- ment, Persistence, and Quality of Creeping Bluestem
}

\section{R.S. KALMBACHER, F.g. MARTIN, AND W.D. PITMAN}

Creeping bluestem (Schizachyrium stoloniferum) was grazed every 60 -days to 15 or 30 -cm stubble heights during the following 4 periods (seasons): (1) June, Aug., Oct. (JAO); (2) Oct., Dec., Feb. (ODF); (3) Feb., Apr., June (FAJ); (4) year-long (YL). Average diameter $(37 \mathrm{~cm})$ of plants grazed in JAO and YL to $15-\mathrm{cm}$ stubble was less $(P<0.05)$ than plants $(43 \mathrm{~cm})$ grazed to $30 \mathrm{~cm}$. There was no difference in diameter of plants grazed to 15 and $30-\mathrm{cm}$ stubble in ODF and FAJ $(45 \mathrm{~cm})$. Tiller density was influenced by stubble height only in 1982 and 1983 when density for the $15 \mathrm{~cm}$ stubble averaged $111 / \mathrm{m}^{2} \mathrm{vs.} 142 / \mathrm{m}^{2}$ for the $30-\mathrm{cm}$ stubble. Tiller density in 1980,1982 , and 1983 was less $(P<0.05)$ in JAO and YL treatments $\left(109 / \mathrm{m}^{2}\right)$ than in ODF and FAJ $\left(167 / \mathrm{m}^{2}\right)$. Forage dry matter yield in 1979-80 and 1982-83 depended on stubble height and seasons. Average yield at $15-\mathrm{cm}$ height was greater for the FAJ treatment $(1,700 \mathrm{~kg} / \mathrm{ha})$, simllar for JAO (910 kg/ha) and ODF (910 kg/ha) and lowest for YL $(660 \mathrm{~kg} / \mathrm{ha})$, but yield was similar at all seasons $(510 \mathrm{~kg} / \mathrm{ha})$ at $30-\mathrm{cm}$ stubble. Crude protein and IVOMD were influenced more by grazing time within a season than by seasons or stubble height. Poorest quality forage was at the beginning of the seasons (especially ODF and FAJ treatments). Best quality came from regrowth. Winter or spring grazing resulted in better stands of creeping bluestem than summer or year-long graxing.

Creeping bluestem (Schizachyrium stoloniferum), a rhizomatous native grass, has been recognized as one of the most important on Florida's flatwoods range (Yarlett 1963), but it often constitutes a small part of the plant community because of poor management. Stands of creeping bluestem can frequently be improved by tandem chopping and deferment for a single growing season (Yarlett 1965, Yarlett and Roush 1970). However, ranchers cannot always defer a pasture for an entire growing season, so they need to know

Authors are agronomist, Ona Agricultural Research Center, Ona, Florida 33865; statistician, Univ. of Florida, Gainesville 32611, and associate agronomist, Ona Agricultural Research Center.

The article is Florida Agr. Exp. Sta. Pa. No. 5516.

Manuscript accepted 29 August 1985. how to graze flatwoods range while allowing the spread of creeping bluestem. Once established they need to know how to maintain stands through proper grazing management.

Some insight into maintenance of established stands can be obtained from results of clipping studies with creeping bluestem and related species. Yield of creeping bluestem cut on 10-week intervals in Florida from June to October was significantly lower after 3 years than forage harvested from October to February (Kalmbacher et al. 1981). Yield depended on height of cut, and could not be maintained after 3 years with a $10-\mathrm{cm}$ stubble height (vs $20 \mathrm{~cm}$ ) regardless of when cutting occurred. Little bluestem (Schizachyrium scoparium) yields in Missouri increased when cut in the dormant stage as compared to cutting in earlier stages of development (May to August) (Vogel and Bjugstad 1968). When little bluestem was grazed in Oklahoma, moderate grazing resulted in greater stands than heavy grazing (Hazell 1967). Tiller number of little bluestem has been shown to decrease with summer clipping in Missouri and Texas (Vogel and Bjugstad 1968, Jameson and Huss 1959).

These reports suggest that grazing creeping bluestem in summer could have adverse effects on rate of spread, tiller number, and sustained yield. The purpose of this investigation was to graze creeping bluestem at various seasons to 2 stubble heights to provide information for ranchers about time and intensity of grazing.

\section{Materials and Methods}

Research was conducted at the University of Florida's Ona Agricultural Research Center in south central Florida. The experimental area was an unlimed, unfertilized Pomona fine sand (sandy, siliceous, hyperthermic, Ultic Haplaquod) with a pH of 4.0 and double acid extractable $\mathrm{P}, 6 ; \mathrm{K}, 75 ; \mathrm{Ca}, 550$; and $\mathrm{Mg}, 115$ $\mathbf{k g} / \mathbf{h a}$.

Existing vegetation was destroyed by disking in December 1975. Creeping bluestem was established vegetatively by hand sprigging tillers ( 3 to 8 per cluster) from an adjacent native area. There were 36 "plants" established on 1.22-m centers in each of $36,6.1 \times 6.1-\mathrm{m}$ treatment plots in January 1976. Plants were not limed, fertilized, 
or burned during the 7-year period.

Eight grazing treatments plus an ungrazed check were studied in a randomized, complete block design. Grazing treatments consisted of forage removal to 15 and $30-\mathrm{cm}$ stubble heights, and there were 4 times of grazing. Grazing was done on 60-day intervals: June, August, October (JAO); October, December, February (ODF); and February, April, June (FAJ), and 6 times per year, every 60-days year-long (YL) beginning in June.

Grazing began in June 1977 with halter broken steers that were placed within portable enclosures (Kalmbacher 1980) and permitted to graze to the proper stubble height. A single steer was placed on each of 4 replications. Grazing to $30-\mathrm{cm}$ stubble height required 4 to 8 hours, while $15-\mathrm{cm}$ stubble grazing required 10 to 14 hours. When soil was saturated after periods of excessive rain, cattle were not put in the enclosures to minimize disturbanco

Grazing was in 2 cycles: first from June 1977 to June 1979 and the second from June 1980 to June 1982. In 1979-80 and 1982-83 each $6.1 \times 6.1 \mathrm{~m}$ plot was clipped for dry matter yield determination with a rotary type plot harvester with height adjustable wheels. Harvest stubble height and time was the same as when grazed. Dry matter was determined by oven drying sub-samples at $60^{\circ} \mathrm{C}$ for 48 hours.

Plant diameter, as indicated by the extent of rhizome spread, was measured in April and August 1976, April 1977, February and September 1978, and September 1979. Tiller density was determined by counting the number of tillers $/ 0.25 \mathrm{~m}^{2}$. Within each $6.1 \times$ $6.1-\mathrm{m}$ plot, tillers in 10 permanent quadrats were counted on diagonal transects. Counts were taken in April 1976, September 1979, October 1980, June 1982, and June 1983. Counts in April 1976 were made with the $0.25-\mathrm{m}^{2}$ frame centered on the tiller cluster, but thereafter quadrats were located on inter-plant spaces.

Crude protein (Gallaher et al. 1976, Issac and Johnson 1976) and in vitro organic matter digestibility (IVOMD) (Moore and Mott 1974) were determined from samples which were hand selected prior to grazing in 1977-78 and 1978-79. Samples were randomly collected in 1979-80 from machine harvested forage.

Data were analyzed by analysis of variance. Significant main effects and first order interactions were further investigated using Duncan's multiple range test or regression techniques depending on whether the factor was qualitative or quantitative. Because of the unbalanced structure, forage quality data were analyzed using the general linear model procedure from Statistical Analysis System (Helwig and Council 1979). Forage quality data were plotted with the curves determined empirically to indicate general trends. Unless otherwise stated, all statistical tests were performed using a significance level of $5 \%$.

\section{Results and Discussion}

\section{Plant Spread}

Monitoring grazing to 15 or $30-\mathrm{cm}$ stubble height turned out to be a subjective approximation of stubble height because grazing was not uniform. Although we removed cattle when average stubble height was 15 or $30 \mathrm{~cm}$, it should be noted that some areas were more heavily grazed, while others were untouched, especially in the $30-\mathrm{cm}$ stubble height. Our observations were similar to those of Gammon and Roberts (1978), who reported that frequent light defoliation was rare, and more frequently grazed tillers tended to be more severely defoliated.

\section{Stubble height}

Average plant diameter depended on stubble height and season. When comparisons are made between stubble heights within seasons, grazing to a $30-\mathrm{cm}$ stubble resulted in larger diameter plants than grazing to a $15-\mathrm{cm}$ stubble in JAO and YL treatments (Fig. 1). There was no difference in plant diameter in 15 or $30-\mathrm{cm}$ stubble height in ODF and FAJ grazing periods. Plants were relatively dormant at these times, while new tillers were actively growing in JAO and YL treatments. When comparing grazing treatments

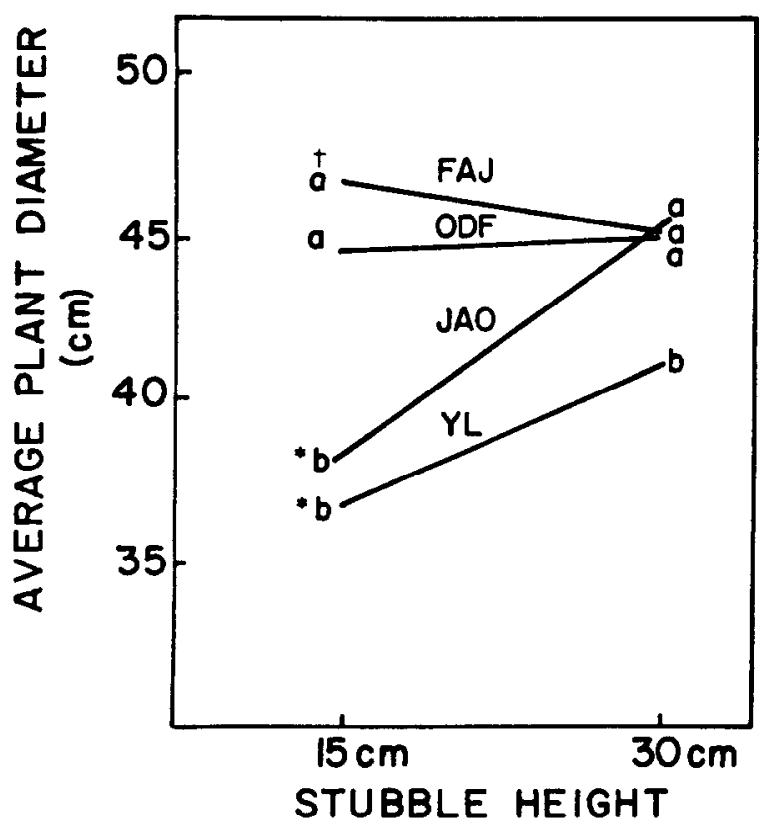

Fig. 1. Spread of creeping bluestem as affected by stubble height and season of grazing. Bluestem grazed at 60-day intervals: June to October (JAO); October to February (ODF); February to June (FAJ); and year-long (YL). Ona, Florida. April 1976 to Sept. 1979.

$\uparrow$ Within a stubble height, means followed by the same letter are not different (Duncan's $M R T, \mathrm{P}<0.05$ ).

*Indicates significant difference $(\mathrm{P}<0.05)$ between stubble heights.

within stubble heights, plants grazed to $15 \mathrm{~cm}$ had greater diameter in FAJ and ODF treatments as compared to JAO and YL treatments. Grazing to $30 \mathrm{~cm}$ resulted in a smaller plant diameter $(P<0.05)$ in the $Y L$ treatment as compared to JAO, ODF, and FAJ treatments. Grazing in ODF and FAJ periods, regardless of stubble height, or JAO treatments in the $30 \mathrm{~cm}$ height resulted in plant diameters that were not different from ungrazed areas where plant diameter averaged $44 \mathrm{~cm}$.

Effect of stubble height on plant diameter also was found to depend on time since initial grazing. A linear relationship provided an excellent approximation accounting for nearly all $\left(R^{2}=0.94\right)$ of the interaction sum of squa res. Diameter of plants grazed to $15 \mathrm{~cm}$ stubble is described by the equation, $-0.237+0.064 \mathrm{~T}$, and for $30-\mathrm{cm}$ stubble; $-2.798+0.072 \mathrm{~T}$, where $\mathrm{T}$ is the number of days since 1 Jan. 1976. Since the standard error of the slopes was 0.004 , grazing to $30 \mathrm{~cm}$ resulted in a faster rate of spread than grazing to $15 \mathrm{~cm}$. Only at the September 1979 sampling date did the 30-cm stubble treatment $(96.7 \mathrm{~cm})$ have a greater $(P<0.05)$ diameter than plants grazed to $15-\mathrm{cm}$ stubble $(86.0 \mathrm{~cm})$.

\section{Season of Grazing}

No differences in plant diameters were found before grazing began in June 1977 (Fig. 2). By February 1978 plant diameter was greater in FAJ than ODF and YL treatments, while the JAO grazing treatment was intermediate, and not significantly different from FAJ or ODF and YL treatments. The reasons for this were that the FAJ treatment had not been previously grazed, the ODF and YL treatments had been subjected to grazing during the preceding period, and the $\mathrm{JAO}$ had undergone a 4-month rest since grazing. Stubble height influenced $(P<0.05)$ plant diameters after 27 months of grazing (Sept. 1979), but 8 months after the start of grazing, plant diameters in JAO and YL treatments were lower than FAJ or ODF treatments. By September 1978, ODF and FAJ treatments had significantly $(P<0.05)$ greater plant diameters than JAO and YL treatments. Finally, in September 1979, FAJ and ODF treatments were significantly greater than the JAO treat- 
ment, while the YL treatment was lower than all others. Since rhizomes from adjacent plants were starting to meet by September 1979 , those measurements were terminated.

Linear regression equations fitted for each treatment explained nearly all $\left(R^{2}=0.94\right)$ of the observed variation in average plant diameter (Fig. 2). Standard error of the slopes was 0.006 . These

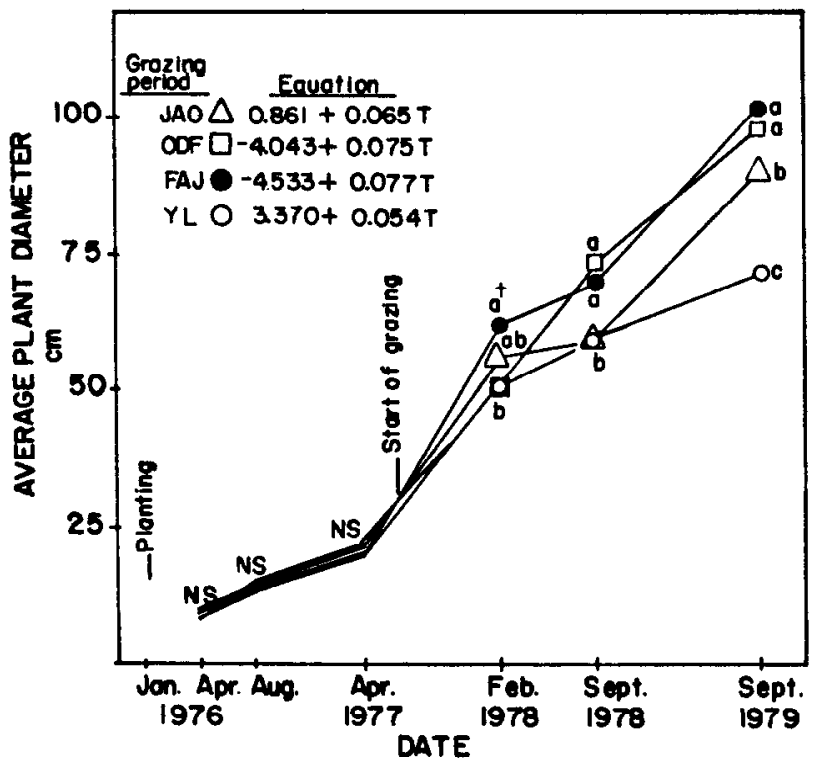

Fig. 2. Effect of season of grazing on creeping bluestem plant diameter. Bluestem was grazed at 60-day intervals June to October (JAO); October to February (ODF); February to June (FAJ); year long $(Y L)$. In the equations $T$ is time in days since 1 Jan. 1976. Ona, Florida.

$\dagger$ Means within a date followed by the same letter are not different (Duncan's MRT, $\mathrm{P}<0.05$ ).

equations illustrate that rate of spread is faster for creeping bluestem grazed in winter and spring or fall and winter as compared to summer and fall or grazing every 60 days, year-long.

\section{Tiller Density}

\section{Stubble Height}

Tillers that were on the edge of expanding plants were usually consumed first at both intensities. Expanding and immature leaves were defoliated more frequently than older leaves (Hodgson 1966). While vegetation toward the center, older region of the plant was more rank and cattle would graze to the prescribed height, tillers on the edge were grazed to within $3 \mathrm{~cm}$ of the soil. It appears that this grazing activity negated early differences in tiller density due to stubble height treatments and resulted in a slower rate of spread.

Therefore, grazing to either stubble height did not have a significant influence on tiller density during the first grazing cycle (data not in table). However, during the second grazing cycle, when creeping bluestem covered a larger area, stubble height had a significant effect on tiller density, which was lower $(P<0.05)$ in both years in $15-\mathrm{cm}$ stubble height $\left(111\right.$ tillers $\left./ \mathrm{m}^{2}\right)$ as compared with $30-\mathrm{cm}$ stubble $\left(142 / \mathrm{m}^{2}\right)$. Plant diameter and tiller density, which are both measures of vigor, were unaffected by stubble height in early stand development, but both were lower when grazed to 15-cm stubble once bluestem was more fully established, as in the second grazing cycle. Cattle did not selectively graze the edges of plants in more solid stands, but grazed throughout the plots. A relatively large portion of tillers were ungrazed even at these high grazing pressures. Briske and Stuth (1982) also observed a large percentage of ungrazed tillers on range grazed with 11 steers / 1.5 ha for 11 days. Although data were not obtained, it is believed a greater percentage of tillers were defoliated-and defoliated more severely-at the $15-\mathrm{cm}$ stubble treatment.

\section{Season of Grazing}

Tiller density was uniform in April 1976 before grazing began (Table 1). After the first year (1977-78) of the first grazing cycle there were still no differences $(P<0.05)$ in tiller density among the four seasons of grazing. After the second year (1978-79) of grazing, tiller density in ODF and FAJ treatments were not different from

Table 1. Effect of month of grazing (or ungrazed) on tiller number of creeping bluestem. Ona, Florida. 1976-1983.

\begin{tabular}{|c|c|c|c|c|c|c|}
\hline \multirow[b]{2}{*}{ Year } & \multicolumn{6}{|c|}{ Months $\dagger$ grazed at 60 -day intervals } \\
\hline & JAO & ODF & FAJ & $\overline{Y L}$ & Avg. ${ }^{\mathfrak{L}}$ & Ungrazed ${ }^{£}$ \\
\hline & & & -nun & $\begin{array}{l}r / \mathbf{m}^{2} \\
\text { alt }\end{array}$ & & \\
\hline 1976 & $6 a$ & $6 \mathrm{a} 8$ & $5 \mathbf{a}$ & $6 a$ & $6 y$ & $6 y$ \\
\hline $\begin{array}{l}1977-78 \\
1978-79\end{array}$ & $\begin{array}{r}37 a \\
140 b\end{array}$ & $\begin{array}{r}47 a \\
182 a\end{array}$ & $\begin{array}{c}\text { irst gr } \\
30 \mathrm{a} \\
175 \mathrm{a}\end{array}$ & $\begin{array}{c}\text { ag cyc } \\
40 \mathrm{z} \\
96 \mathrm{c}\end{array}$ & $\begin{array}{r}\text { \# } 63 y \\
148 z\end{array}$ & $194 y$ \\
\hline $1980-83$ & \multicolumn{6}{|c|}{ Second grazing cycle } \\
\hline
\end{tabular}

†JAO, June to Oct.; ODF, Oct. to Feb.; FAJ, Feb. to June; YL, year-long.

fInitial tiller counts centered on creeping bluestem plants, while those of 1979 to 1983 were taken on the inter-plant spaces.

$\$$ Means within the four month-groupings followed by the same letter are not different (Duncan's multiple range test, $P$ 0.05).

For comparison of avg. grazed vs. ungrazed.

\#Means from the first grazing cycle separated duc to year $\times$ time (month) interactions.

each other, but they were greater in tiller density than the JAO treatment. The YL treatment had fewer tillers than all other treatments. Average tiller densities of all the grazed treatments were lower $(P<0.05)$ than the ungrazed treatment each year of the first cycle.

There were significant differences in tiller densities among grazing seasons during the second grazing cycle, and since the response was similar in each year, tiller densities were averaged in Table 1. The FAJ treatment had significantly more tillers $/ \mathrm{m}^{2}$ than the JAO treatment, while ODF treatment was intermediate. The YL treatment was significantly lower than FAJ and ODF treatments, but not different from the JAO treatment. No difference was found between the average of all grazed treatments and the ungrazed treatment.

\section{Forage Yield \\ Stubble Height}

Average forage yield was greater $(P<0.05)$ in the $15-\mathrm{cm}$ than 30 -cm stubble height during JAO, ODF, and FAJ grazing treatments, but there was no difference in stubble height in YL treatment (Fig. 3). Average annual forage yield was different $(P<0.01)$ in the $15-\mathrm{cm}(1,050 \mathrm{~kg} / \mathrm{ha})$ vs the $30-\mathrm{cm}$ stubble $(520 \mathrm{~kg} / \mathrm{ha})$. Previously, creeping bluestem yield could not be sustained by clipping for 2 consecutive years at a $10-\mathrm{cm}$ (vs $20-\mathrm{cm}$ ) stubble height, because yield at $10 \mathrm{~cm}$ declined and was not different from yield at $20-\mathrm{cm}$ stubble (Kalmbacher et al. 1981). This disparity between the 2 studies reflects differences in method of defoliation and stubble height.

Forage yield at $15-\mathrm{cm}$ stubble was greater $(P<0.05)$ during FAJ than $O D F$ and $J A O$ treatments, which were not different, while the YL treatment was lowest (Fig. 3). For the $30-\mathrm{cm}$ stubble height, yield in the FAJ treatment was higher than YL, JAO, and ODF, which were not different. These data are in agreement with results from earlier work (Kalmbacher et al. 1981) and indicate that defoliation on 60-day intervals June to October resulted in lower yield than repeated October to February defoliation.

To put these yield values in perspective, they are not estimates of total creeping bluestem yield, which can be as much as $2,200 \mathrm{~kg} / \mathrm{ha}$ for pure stands (Kalmbacher 1981), but they are estimates of 


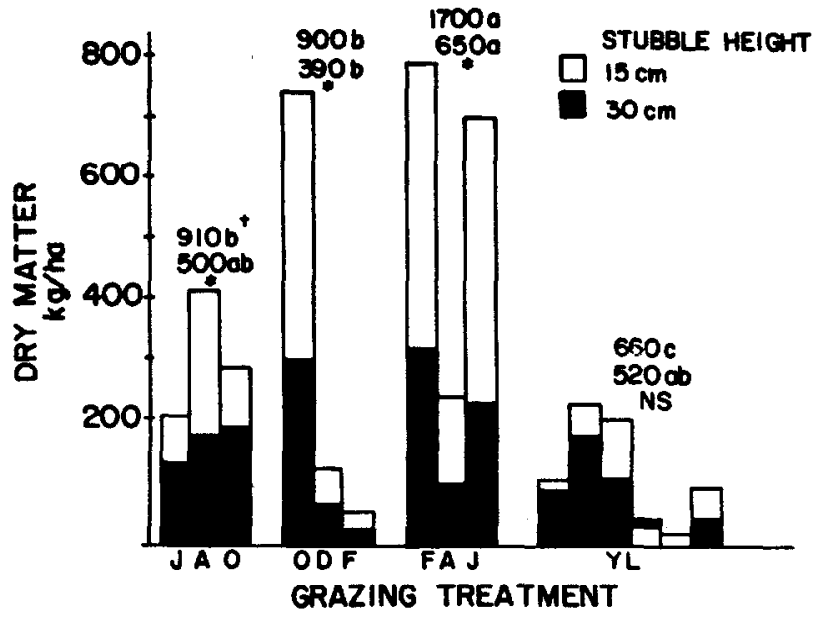

Fig. 3. Estimates of the yield of grazable creeping bluestem as affected by stubble height and season of grazing averaged over 1979-80 and 1982-83. Bluestem was grazed June 1977 to 1979 and 1980 to 1982 on 60-day intervals June, Aug., Oct. $(J, A, O)$, Oct., Dec., Feb. (O,D,F), Feb., Apr., June $(F, A, J)$, or year-long $(Y L)$. Ona, Florida.

* Stubble heights significantly different $(\mathrm{P}<0.05)$ within a season, NS not significant.

†Means within a stubble height followed by the same letter are not different (Duncan's MRT, $\mathrm{P}<0.05$ ).
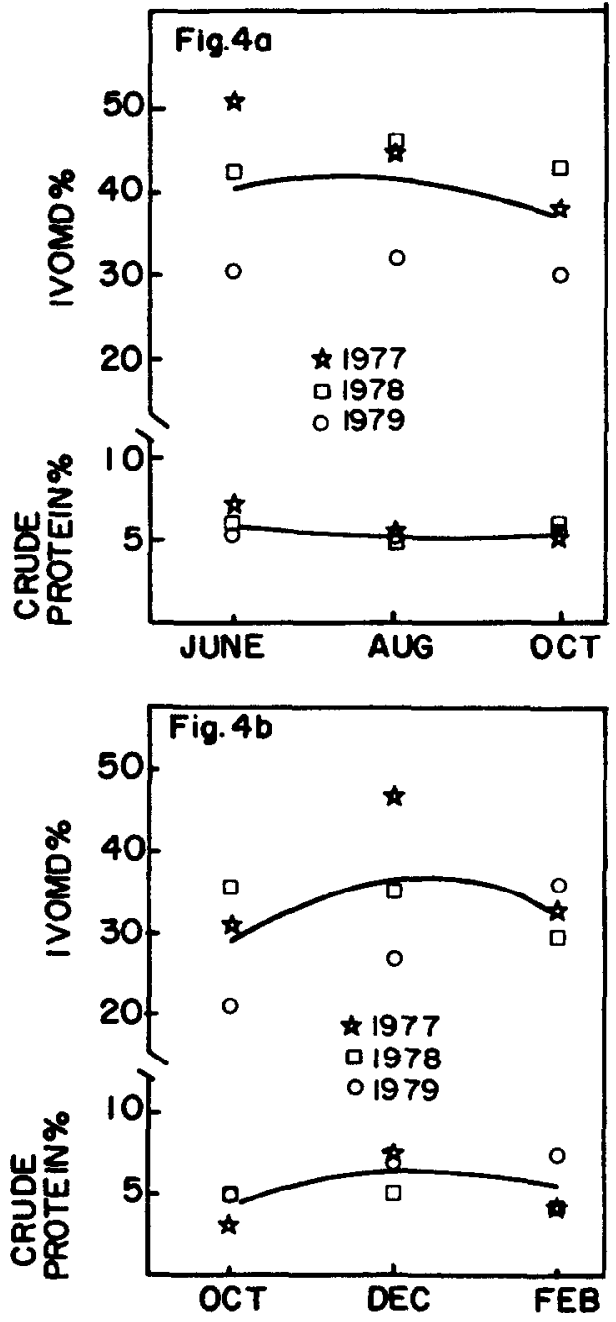

grazable forage in pure stands. Pure, solid stands are not common, but creeping bluestem could easily compose 50 to $75 \%$ of the grazable forage on flatwoods range. Although creeping bluestem is a major constituent of the diet (Kalmbacher et al. 1984), the amount actually eaten relative to the amount produced is small. On 2 well-grazed flatwoods pastures in good condition where total yield of creeping bluestem was 340 and $410 \mathrm{~kg} / \mathrm{ha}$, only 50 and $58 \%$ were utilized (Long 1983).

\section{Forage Quality}

There were no significant $(P<0.05)$ differences in main effect means for crude protein and IVOMD among the JAO, ODF, FAJ, and YL treatments. The stubble height $\times 60$-day period within season interactions were significant for both crude protein and IVOMD in all 3 years when these parameters were measured. Effect of stubble height will be discussed independently of time with more emphasis on the effects of 60-day period within season, which had the strongest influence.

Crude protein and IVOMD were not significantly influenced by stubble height in 1977-78 or 1979-80, but in 1978-79 both responses were greater $(P<0.05)$ in the $15-\mathrm{cm}(5.8 \%$ protein, $41.2 \%$ IVOMD) vs 30-cm (5.3\% protein, 38.7\% IVOMD) stubble. Protein and IVOMD in other years were numerically larger in the 15-vs 30-cm stubble.

Crude protein in the JAO treatment declined from June (6.3\%) to August (5.2\%) and increased in October (5.7\%) (Fig. 4a); a trend previously observed and discussed (Kalmbacher et al. 1985).
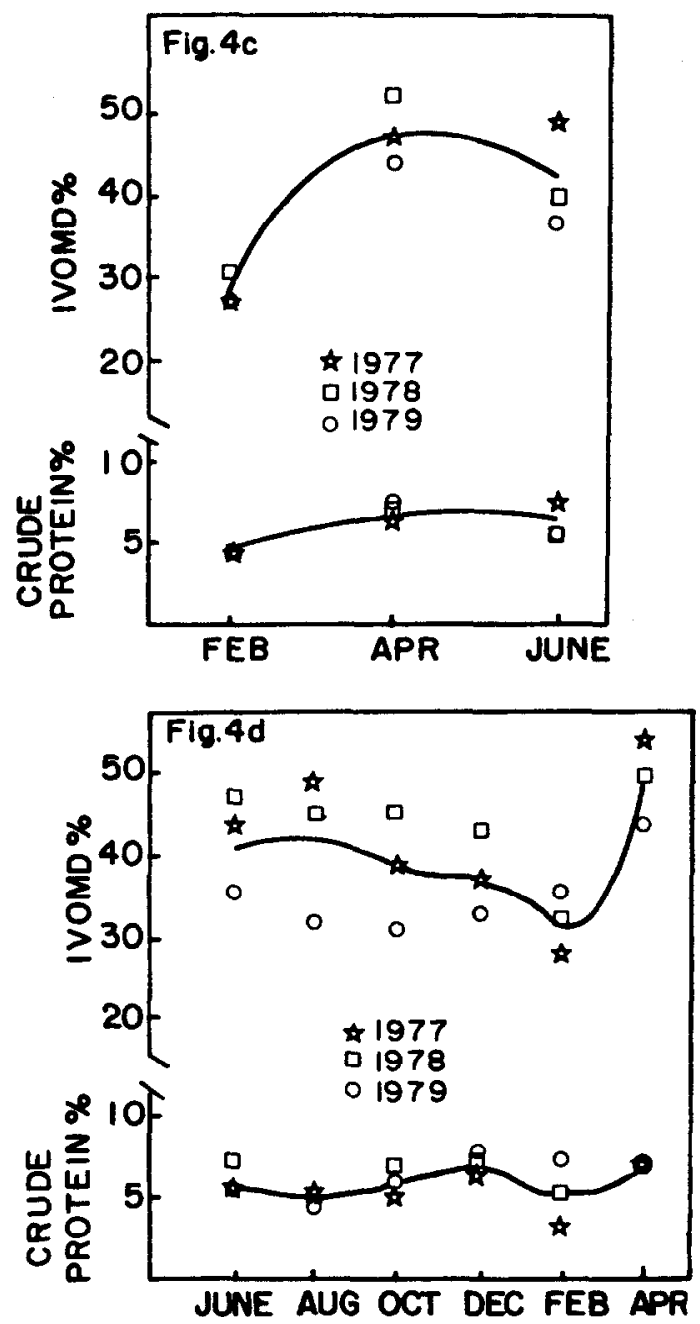

Fig. 4. Crude protein and in vitro organic matter digestibility (IVOMD) in creeping bluestem in (a) June, Aug., Oct.; (b) Oct., Dec., Feb.; (c) Feb., Apr., June; and (d) June, Aug., Oct., Dec., Feb., Apr. Ona, Florida. 1977, 1978 and 1979. 
IVOMD varied widely over years, and no distinct trend within the JAO treatment was found. Since samples for analysis were collected from the harvester in 1979, and not hand-selected as in the former 2 years, 1979 IVOMD percentages for most treatments tended to be lower than those for former years.

Crude protein and IVOMD in ODF (Fig. 4b) and FAJ treatments (Fig. 4c) followed similar patterns. Because forage was produced in the previous growing season and carried over to fall or winter, respectively, average protein $(4.4 \%)$ and IVOMD $(29.1 \%)$ of the first sampling in ODF and FAJ started out low. Protein $(6.7 \%)$ and IVOMD $(42.2 \%)$ increased at the second, but declined (5.9\% and $37.5 \%)$ in the third 60 -day sampling period. Cool-season regrowth (i.e., December to April), which contained more protein than summer regrowth (Kalmbacher et al. 1981, Kalmbacher et al. 1985), may have good quality, but quantity is extremely low (Fig. 3 ), therefore of little consequence. The amount and quality of forage at the beginning of ODF or FAJ periods is important to the rancher, because that is the forage on offer during winter and spring.

Crude protein in the YL treatment (Fig. 4d) followed a seasonal pattern influenced by regrowth (Figs. 4a, b, c). The YL treatment remained relatively high in protein because of repeated defoliation. IVOMD of the YL treatment at any month was comparable to higher IVOMD of regrowth of other treatments at that respective time.

\section{Application of Results}

Season of grazing creeping bluestem may be of greater importance than extent of defoliation on range where the sward has been opened-up by chopping, web-plowing, or burning. During the 2 to 3 years required for creeping bluestem stands to improve, grazing should be conducted in fall and winter. When bluestem becomes a major portion of the sward, it should be grazed to about $15-\mathrm{cm}$ stubble height, which is about one-half of the herbage by weight, two thirds by height. Grazing to this height will result in more grazable forage and perhaps better quality than under-grazing to a 30-cm stubble.

Grazing only in winter results in high yield, but poor quality. Grazing year-after-year in summer results in loss of vigor, lower yields and weak stands, but better forage quality. Cows could use creeping bluestem range in a winter/summer combination, deferring range from June to September every other year. Another alternative would be to extend winter grazing into spring, as late as June. Both alternatives may provide less mature, but vigorous stands in fall when range grazing resumes. Burning in summer instead of winter may be useful and should be evaluated.

\section{Literature Cited}

Briake, D.D., and J.W. Stuth. 1982. Tiller defoliation in a moderate and heavy grazed regime. J. Range Manage. 35:511-514.

Gallaher, R.N., C.O. Weldon, and F.C. Boswell. 1976. A semiautomated procedure for total nitrogen in plant and soil samples. Soil Sci. Soc. Amer. Proc. 40:887-889.

Gammon, D.M., and B.R. Roberts. 1978. Patterns of defoliation during continuous and rotational grazing of the Matopos Standveld of Rhodesia. 2. Severity of defoliation. Rhod. J. Agr. Res. 16:133-145.

Hazell, D.B. 1967. Effect of grazing intensity on plant competition, vigor, and production. J. Range Manage. 20:249-252.

Helwig, J.T., and K.A. Council. 1979. S.A.S. Users Guide. SAS Institute. Raleigh, NC.

Hodzson, J. 1966. The frequency of defoliation of individual tillers in a set-stocked sward. J. Br. Grassl. Soc. 21:258-263.

Issac, R.A., and W.C. Johnson. 1976. Determination of total nitrogen in plant tissue using a block digester. J. Ass. of Anal. Chem. 69:98-101.

Jameson, D.A., and D.L. Huss. 1959. The effect of clipping leaves and stems on number of tillers, herbage weights, root weights, and food reserves of little bluestem. J. Range Manage. 12:122-126.

Kalmbacher, R.S. 1980. A versatile livestock enclosure for pasture research. Rangelands. 2:19-20.

Kalmbacher, R.S., F.G. Martin, and J.M.S. Andrade. 1981. Yield and quality of creeping bluestem as affected by time of cutting. J. Range Manage. 34:471-474.

Kalmbacher, R.S., K.R. Long, M.K. Johnson, and F.G. Martin. 1984. Botanical composition of diets of cattle grazing south Florida rangeland. J. Range Manage. 37:334-340.

Kalmbacher, R.S., F.G. Martin, W.S. Terry, D.H. Hunter, and L.D. White. 1985. Effects of clipping on burned and unburned creeping bluestem. J. Range Manage. 38:531-535.

Long, K.R. 1983. Evaluation of Florida range using esophageal fistulated steers. M.S. Thesis. Dep. of Agron. Univ. of Florida Gainesville. 32611.

Moore, J.E., and G.0. Mott. 1974. Recovery of residual organic matter from in vitro digestion of forages. J. Dairy Sci. 57:1258-1259.

Vogel, W.G., and A.J. Bjugstad. 1968. Effects of clipping on yield and tillering of little bluestem, big bluestem, and indiangrass. J. Range Manage. 21:136-140.

Yarlett, L.L. 1963. Some important and associated native grasses on central and south Florida ranges. J. Range Manage. 16:25-27.

Yarlett, L.L. 1965. Control of saw palmetto and recovery of native grasses. J. Range Manage. 18:344-345.

Yarlett, L.L., and R.D. Roush. 1970. Creeping bluestem (Andropogon stolonifer (Nash) Hitchc.) J. Range Manage. 23:117-122.
MOVING? Please try to give us four weeks notice. Send your present address label and this form to Society for Range Management

2760 W. 5th Ave.

Denver, Colo. 80204

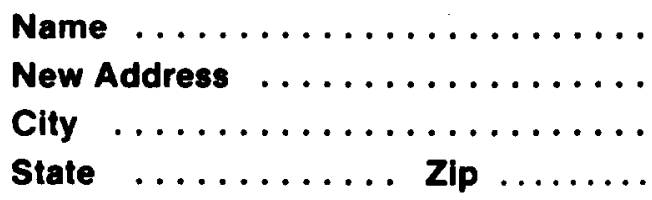

\author{
ATTACH OLD \\ ADDRESS LABEL \\ HERE
}

